\title{
遮閉試験
}

中 村 桂子

大阪医科大学眼科学教室

\section{Cover test}

\author{
Keiko Nakamura \\ Department of Ophthalmorogy Osaka Medical College
}

要 約

遮閉試験は眼位検查とその評価を行う上で、もっとも基本であることは言うまでもない。

臨床的な応用においては、他の検査を実施する前に診断が可能な場合も少なくない重要な診断法で ある。本報では、筆者が実際行っている方法を主体に述べながら、チェックすべきポイントを再確 認し、今後の臨床応用にもふれてみた。

1. 遮閉試験を行う上での注意点の再確認として調節視標の重要性、遮閉に用いるカバーの使い分 けを検討。

2. 間歇性外斜視の手術前の偏位角の測定において、潜伏された偏位を引き出す方法を工夫。

3 . 遮閉試験は第一眼位での検査が中心であるが、眼球運動の全体像を知るためには、むき眼位の 検査が重要である事を示し、臨床的には 5 方向カバーテストや 3 方向カバーテストが有用であ り、頭部傾斜試験も遠見視下での検查を推奨する。

4. 斜視手術後の検查で眼球運動の不均衡を定量し、その動きの回復程度を見ていくための評価方 法として、3 方向カバーテストは役立つ。

5 . 眼筋麻㽻への応用にも触れ、遮閉試験の不向きな症例にも触れる

別冊請求先（テ569-8686）高柣市大学町 $2-7$

大阪医科大学眼科学教室 中 村 桂子

Tel. 0726-83-1221 Fax. 0726-81-8195

Key words : 遮閉試験, 調節視標, 眼位, 融像除去眼位, むき眼位, cover test, accommodation target, eye position, fusion-free eye position, positions of gaze 


\section{I ははじめに}

遮閉試験（Cover test）は斜視や両眼視機能 異常の検査の入口であり、また出口でもある。 当シンポジウムのテーマである眼位検査におい て基本であることは言うまでもなく、臨床的な 応用においては他の検査を実施する前に診断が 可能な場合も少なくない重要な検査法である。 本報では筆者自身が実際に臨床で行っている方 法を主体に述べ、チェックすべきポイントを再 確認した上で利点、問題点を検討し、今後の臨 床的な応用についても考えてみたい。

\section{II . 遮閉試験の意義・目的・種類}

遮閉試験は日常視下の斜視の感覚面と運動面 の状態を、定性的かつ定量的にとらえることの 出来る臨床上、有用な検査法である ${ }^{1) ~-6) 。 ~}$ 遮閉試験を行う前に、まず視診にて 9 方向眼位 のチェックやHirschberg法を行い、大まかな情 報を得て、次に遮閉試験に入る。遮閉試験には 表 1 のような種類があり、最も大切なのは、(1) のcover uncover testで、まず慎重に定性を行 うことが遮閉試験の基本である。そこで斜位で あるか斜視であるか、眼位ずれの方向など確認 する。(2)のalternate cover testは融像を除去し、 全斜視角の測定が可能である。(3)のプリズムを 用いて定量的に行う検査はあくまで次の段階の 位置付けとなる。SPTという略で呼ばれる検 査の中には single prism cover testと simultaneous prism cover test（同時プリズム遮 閉試験）という二つの言葉が少し曖昧に用いら れているが、後者の検査テクニックはプリズム

表 1. 遮閉試験の種類

\section{(1) cover-uncover test（ CUT ) \\ (2) alternate cover test ( ACT ) \\ (3) prism cover test ( $\mathrm{PCT}$ )} single prism cover test ( SPCT ) alternate prism cover test ( APCT )

(4) screen-comitance test ( SCT
とカバーを同時に入れて眼の動きをすばやく観 察しなければならず、熟練を必要とするので、 臨床的には筆者自身は二つを併用したような手 技で検査している。具体的にはプリズムバーを 常時 1 眼の前に置いたまま他眼をcover uncover testし、プリズム度を変えていくと人工的な感 覚をつくってしまい日常視の感覚から遠ざかる ので、時々プリズムバーをはずし、両眼開放で 自然視の状態に戻し、プリズムバーを入れるの とカバーをするのを少し時間差を付けなから simultaneous prism cover testの手技を加えて検 査をしている。

\section{III. 遮閉試験を行う上での注意点の 再確認}

日常、施設により遮閉試験を行う時の細かな 手技などに違いが見られることが多いので、固 視目標の問題、遮閉に用いるカバーの問題、プ リズムの当て方、被験者の位置、固視に必要な 視力などの注意点について再確認しておきたい。 この報告に先立ち、現状調查を行うために視能 訓練士協会の理事各位にアンケートを送らせて 頂き、現状調査をさせていただいた。

1 . 固視目標

まず固視目標についてみてみると、日常、私 達は当然調節を使ってピント合わせをして物を 見ているので、日常眼位を測定するためには、 調節視標が基本となる。第15回視能訓練士協会 講演会で金谷氏は「全ての斜視の眼位検査にお いて重要なことは“調節をコントロールするた め”に必ず調節視標を使うことであり、調節を コントロールするということは調節をさせると いう意味ではなく、見ようとするものに対して 適切な調節状態を作り、保たせるためである。」 と述べ、注意点として「調節視標でもただ見せ るだけではなく、不必要な調節を取り除くため に、絵視標であれば “おひげは何本あるかな?” とか“お口の中に誰がいる?”とか絶えず聞き ながら検査したり、文字視標なら“見て”とい うだけでなく“読ませる”ことが大切である」 と述べている ${ }^{7)}$ 。光視標は理想的には無調節下 の眼位を測っているつもりでも、光視標は常に 
完全に無調節という保証はなく、調節の介入が 不安定である。

眼位検查時に実際に用いている固視目標につ いてのアンケートの結果（1）を図 1 に示す。 予想に反して $30 \%$ 以上の方が光視標を使われて いる事に驚いた。内斜視は調節と輻湊の関連性 が強いので、外斜視より調節視標の使用が $57 \%$ と多かったが、それでも光視標を使っている所 が多かったことは残念である。また、外斜視は 光視標で測る方が良いと理解されている所もあ った。金谷氏も述べているようにあくまで、眼 位を定量的に検査する時の基本は調節視標で行 うべきで、外斜視で光視標を用いると調節が関 与しにくく偏位が大きくでるという考え方は思 い違いである。金谷氏はその反対例なども紹介 して説明をしている。

実際の視標としては、出来るだけみんなが知 っているキャラクターを選び使っている。中心 に何か印があるものほど固視しやすく、はっき りした色あいのものが適している。小児の場合、 検查に集中させるために、自分で固視標を持た せることも効果的である。また、検者が検者用 に装用するメガネフレームの中心にシールを貼 って固視標に使う方法も、検者の両手が空くの で有利である。

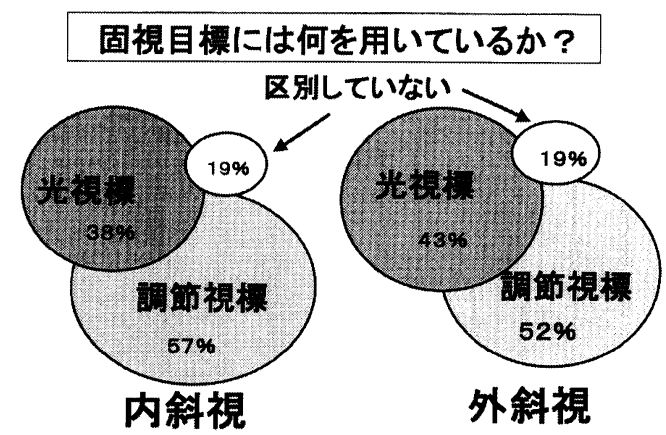

図 1.アンケートの結果 $(1)$

\section{2 . 遮閉具}

遮閉具についてのアンケート調査では、市販 のものより厚紙や下敷きなどを利用した手作り のものが良く用いられていた。約 3 割の方が半 透明のものと光を通さないものとを使い分けら れており、特に交代性上斜位や教育用、説明用 には半透明のものを使うと回答があった。眼筋
麻痺などの二次偏位の動きなどをチェックする 時も役立つ。半透明のものにはスピールマン、 トランスルーセントオクルーダーなどがよく使 われているが、クリアーホルダーを適当な大き さにカットし、 5 枚を 1 セットとした、手作り のものも用いられている。枚数を変えることに より斜位を保つ能力の検討などの研究的なテー マに取り組んでいる施設もある。

しかし、眼位検査においては光を通す遮閉具 では融像が完全に破れないことが問題である。 やはり、定量には不向きと考える。カバーの材 質では、光沢のあるものは子供の視線がその遮 閉具自身に向きやすいのであまり適さない。も っとも重要なポイントは光を通すかどうかとい うことで、眼位の定量には光を通さない材質の ものが適していると考える。

また経験的には、特に廃用性弱視などの視力 不良例において、半透明のカバーでは隠された 方の健眼を使って見ようとするので、患眼の正 確な見直しの動きが確認しにくく、やはりこの ような場合は完全に光を遮断する材質のもので カバーしなければならない。また、乳幼児では 検者の親指でカバーすると、拒否反応が少なく スムーズに検査できる時も多い。

\section{3.プリズムの保持方法}

日常臨床において、斜視角の測定にはプリズ ムレンズを用いることが多く、現在、視能矯正 用のプリズムレンズにはプラスチック製のプリ ズムブロックやプリズムバーが汎用されている。 最近はまた、プリズムアダプテーションテスト などに有用なフレネル膜プリズムのトライアル セットも普及してきている。これは臨床的に非 常に役立っている。

正確な測定を行うためのプリズムレンズの保 持方法には、較正位置の違いにより図 2 のよう に三通りの方法がある ${ }^{8)}$ 。プリズムブロックは この左端のminimum deviation positionで較正 されているため、この位置に保持しなければな らない。これは最小偏位角を示す位置で実際、 この位置を保ちながら検査する事は容易ではな い。そこで臨床的には、保持方法の容易さや連 続的な測定が可能なことからプリズムバーが好 まれて使われている。プリズムバーの保持方法 


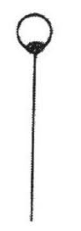

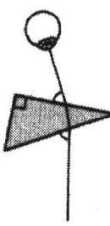

minimum deviation position
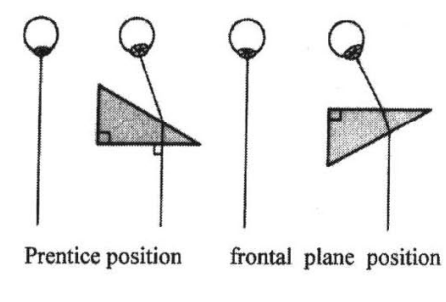

\section{単独プリズム 垂直プリズムパー 水平プリズムバー}

図 2.プリズムレンズの保持方法

は実際にはメーカーによって多少異なっている ようであるが、一般的には垂直プリズムバーは 真ん中のprentice positionで保持し、水平プリ ズムバーはfrontal plane positionで保持するよ うに作られており、実際には水平バーと垂直バ 一の平面を背中合わせにして使用するようにな つている。そこで実際に垂直プリズムバーのみ を使って測定する場合には、水平面が顔の方に 来るように置くにではなく、プリズムのギザギ ザが顔の方に向くような、prentice positionの 位置に置き検査する必要がある。検査時には被 検者の位置や姿勢に気をつけ、出来るだけ視線 の高さを合わせた状態で測定することも大切で ある。また視力不良例の検査では固視出来る視 標かどうかを聞きながら、調節視標が見えにく い場合は、光視標を用いる。

\section{IV . 斜視のタイプによる測定方法の 違い}

1. 見かけの斜視

仮性斜視に見られやすい症例として、内角贅 皮や黄斑偏位や片眼の眼瞼下垂はよく知られて いるが、実際、臨床の場では協力性のない乳児 などでは、この判定がなかなか容易ではない。 図 3 は 1 歳時に来院された時には仮性内斜視だ ろうと診断されていた例で、最近 3 歳になり、 やはり眼位が気になり再度受診され、間歇性外 斜視であることが分かった症例である。1 歳時 に検査が十分出来ずに安易に仮性内斜視と診断 してしまった例で、このようなケースは臨床的 にはまれではない。保護者への説明としては、 今は異常が見られないが、 3 歳ころになってま だ目つきが気になるときは、また受診するよう

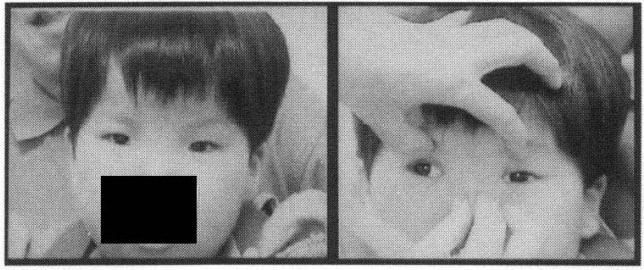

図 3.仮性内斜視に見える間歇性外斜視 に付け加えておくことが大切である。黄斑偏位 がある場合は、角膜反射が両眼とも鼻側にみら れ、見かけ上は外斜視に見え、片眼性の眼瞼下 垂は上斜視に見える。しかし両者とも遮閉試験 では正位なので、鑑別は容易である。

図 4 は黄斑偏位で外斜視が目立つ例である。見 かけの偏位と実際の偏位に差があるので手術時 には慎重な定量が必要となる。

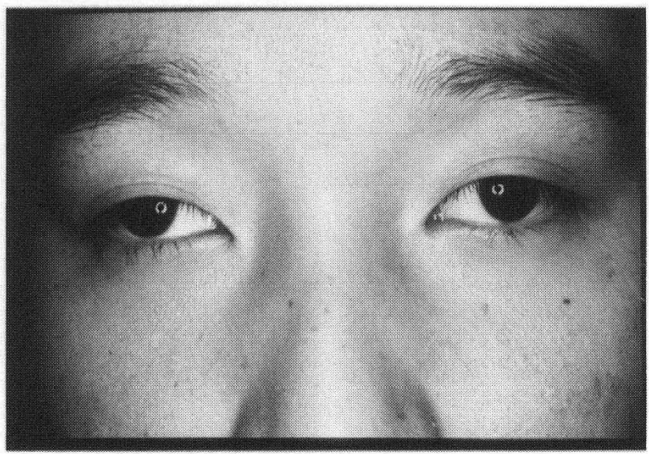

図 4.黄斑偏位による外斜視

2. 内斜視と外斜視の測定方法の違い

内斜視は、調節や緊張によって眼位が変動し やすいので、カバーをする前にまずできるだけ 離れてHirschberg法にて、顕性のずれを把握す る。次にcover uncover testを中心に遮閉の回 数を出来るだけ少なく、手早く検査を行う。 alternate cover testを繰り返すと内斜偏位は増 加することが多いので出来るだけ日常眼位を自 然に捉えるように心がけ、プリズム定量時は single prism cover test（以下 S P C T と略）を 中心に、整復運動がほほ中和されるまで確認す る。

外斜視は臨床的に間歇性外斜視が多いので、 遮閉を長くして、潜伏された偏位を引き出す工 夫が必要である。プリズム定量時にはalternate prism cover test（以下A P C Tと略）にて整 
復運動が逆転するまで確認する。間歇性では正 位の時と外斜視になっている時があり、潜伏さ れた偏位をいかに引き出すかが重要である。恒 常性の外斜視で大斜視角になっている場合は内 転障害に注意する。

\section{$\mathrm{V}$ ．間歇性外斜視の手術前の眼位測 定の検討}

間歇性外斜視の手術量を決定するためには術 前の斜視角の測定が重要である。そこで眼位測 定の方法について検討を行った。

一般的にはAPCTにて融像除去眼位が測定でき ると言われているが、実際には潜伏された偏位 を短時間で引き出すのはなかなか難しい。そこ で、APCTだけで十分に潜伏された外斜偏位が 検出できるのか?、という疑問から、表 2 の三 つの方法で当科外来の 47 例の手術前の外斜視患 者の眼位を測定した。通常の A P C T と片眼40 分遮閉後の A P C T、さらに両眼開放下で40分 間プリズム装用後 A P C Tである ${ }^{9)}$ 〜0)。

表 2 . 外斜偏位を検出するための三つの検查方法

\section{APCTだけで十分に潜伏された外 斜偏位が検出できるか?}

\section{通常のAPCT \\ 片眼40分間遮閉後のAPCT \\ 両眼開放下で40分間 \\ プリズム装用後APCT}

その結果は表 3 のように、片眼遮閉後は融像 除去のため近見斜視角は増えているが遠見に対 しては効果が見られず、両眼開放にて40分間プ リズム装用した後の斜視角は、近見・遠見とも に斜視角が増加した。遮閉することにより不自 然な状態を設定して融像除去するよりも、両眼 開放下にてリラックスさせて、測定した方がも っとも、斜視角が増加する結果となったことは、 興味深い。

理事の方々へのアンケートの結果（図 5 )、
表 3 . 各条件下での斜視角の測定結果

\begin{tabular}{|c|l|c|}
\hline & 近見斜視角 & 遠見斜視角 \\
\hline 負 荷 前 & $27.0 \pm 9.1$ & $25.8 \pm 7.0$ \\
\hline 40分遮閉後 & $33.1 \pm 7.4^{* *}$ & $25.5 \pm 7.4$ \\
\hline プリズム装用後 & $37.6 \pm 9.2^{* *}$ & $31.0 \pm 7.6^{* *}$ \\
\hline
\end{tabular}

** 有意に増加 $(\mathrm{P}<0.0001)$

\section{手術のための定量は何を参考にしているか？}

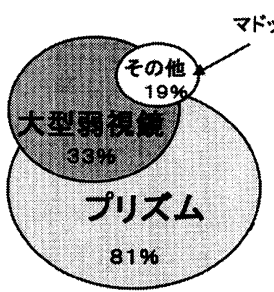

内斜視

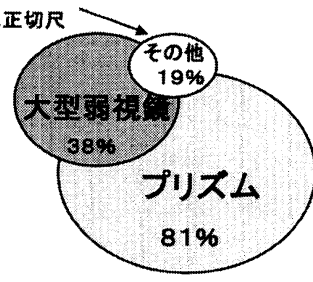

外斜視
図 5。アンケート結果 $(2)$

手術のための定量は何を参考にしているか？と いう質問に対する回答では、もちろん、プリズ ムによる定量を参考にするという答えが多かっ たが、内斜視・外斜視にかかわらず、予想して いた以上に大型弱視鏡のデータが参考にされて おり、少々疑問に感じた。大型弱視鏡での偏位 角測定の問題点は、周知のとおり測定時に近接 性輻湊が入ることで、もし内斜視であれば偏位 角が大きく出るし、外斜視であれば、偏位角が 小さくなる。誰でも同じ程度に近接性輻湊が入 れば問題ないが、その保証がなく均等に入らな いことが問題である。このような理由から、大 型弱視鏡は日常眼位の定量には向かないと考え る。私達はより自然視に近い状態で測定出来る、 A P C Tの結果を参考にしている。

\section{VI． 斜視手術後の眼位測定法}

斜視手術後の眼位測定においては、眼球運動 の不均衡が生じているので、第一眼位のみの眼 位チェックだけでは不十分である。その動きの 回復の程度をみていくための評価法として、少 なくとも水平 3 方向のカバーテストは必要と考 
えている。実際にはA P C T を行う際に、通常 の第一眼位の遠見眼位を測る時に、追加として 左右の側方視時の眼位も定量する。やはり外直 筋の後転により外転が遅動していることが多く、 表 4 のように、手術眼を外転させる方向では $\mathrm{E}$ Tとなることを良く経験する。その時の複視の 自覚も確認する。正面の眼位は術直後から良好 でも側方視での違和感などの訴えを理解する上 でも、このような経過の見方は臨床的に有用と 考える。

表 4 . 水平筋術後の水平 3 方向カバーテスト

\section{APCT(S.C.)}

\section{$\mathbf{N}$ \\ $6 \Delta X^{\prime}$

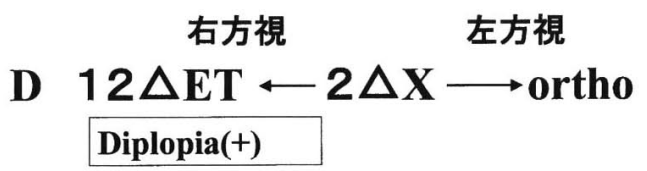

\section{VII．むき眼位の測定法}

次にむき眼位の測定法について考えてみたい。 まず、診察室に入ってくる時の自然な頭位を観 察しておくことが検査のスタートで、次に眼位 の検查は第一眼位が基本となる。しかし眼球運 動のバランスを把握するためには、むき眼位の 検査が重要となってくる。実際、定性的なむき 眼位の検査はよく用いられている。

測定方法は遠見で 1 つの視標を固視させ、被 検者の頭位を変えながら A P C Tにて偏位量を 測定する。外転神経麻瘏、眼窩吹き抜け骨折、 上斜筋麻痺、水平斜視術後などに特に有用であ る。その時は必ず、健眼固視で、麻痺眼の方に プリズムを入れ不自然な二次偏位を生じさせな いことがポイントである。

\section{VIII. 眼筋麻㾝等の応用}

具体的な眼筋麻痺の見方について見ていきた い。外転神経麻瘒の症例は、外転しにくくなっ た方の眼が遠方視するほど内斜視になり、もち ろん同側性の複視を訴える。図 6 のように、近
見より遠見で内斜偏位が増加するのが特徵であ る。視診による 9 方向眼位で肉眼的に外転が弱 いのが分かりにくい程度の時でも、水平 3 方向 のカバーテストの結果では異常が検出しやすく 有利である。通常のカバーテストで、図 6 のよ うに近見の内斜偏位より遠見の内斜偏位が大き いことがポイントである。外転神経麻疩を疑っ たら、麻痺眼方向へのface turnに注意し、次に 水平 3 方向のカバーテストを行う。表 5 のよう に麻痺眼方向で内斜偏位が増加する。検査時に は常に複視の自覚も確認しながら定量する。

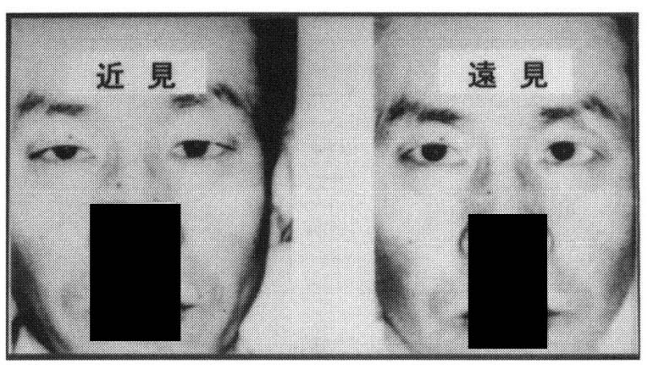

図 6. 外転神経麻痺

表 5 . 外転神経麻疩例の水平 3 方向カバーテス卜

近見のET $<$ 遠見のET

麻㾴眼方向へのFace turnlに注意

水平3方向 CTで麻㾝眼方向 でET up

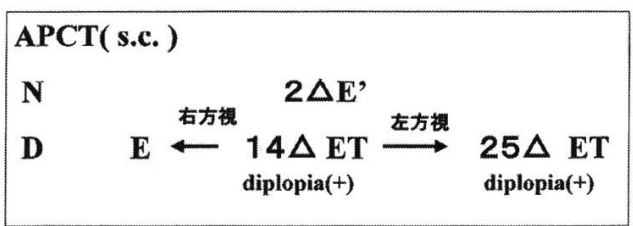

眼窩吹き抜け骨折の症例では 9 方向眼位写真 （図 7 ）のように、右眼は上方視時ほとんど上 転ができない。この疾患は特徵的に上下の眼球 運動が障害されるので、経過をみていく時には、 垂直 3 方向のカバーテストが役立つ。

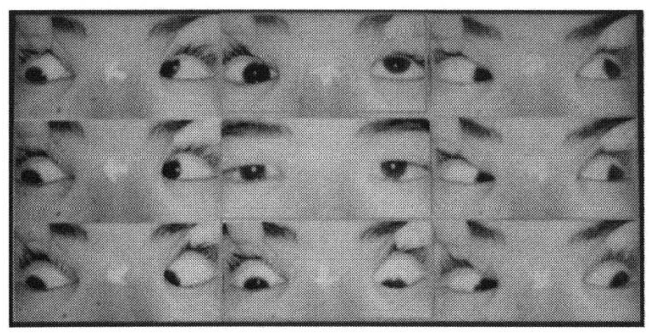

図 7 . 眼窩吹き抜け骨折 ( 9 方向眼位) 
臨床的によく遭遇する上斜筋麻疩では、診断 的検査法としてはParks-3-stepsが有名である。 最終段階のBielschowsky頭部傾斜試験は斜筋の 異常を検出するのに有効である。しかし、実際 どのような条件で検査が行われているか整理す るために、アンケートで調べてみた。その結果 を図 8 に示す。検査距離は意外にも、近見で行 っている施設が多く驚かされた。近見は融像が 働きやすいので、上下の偏位が検出されにくく、 やはり遠見視させた状態で検査を行うほうが上 下偏位を検出し易い。次に定性・定量のどちら を通常行っていますか？という質問に対しては、 定性のみで経過をみている所が多かった。私自 身は星印のついた方法の遠見固視で定量まで行 う方法を通常の測定方法とし、とくに手術を考 えながら経過をみる時にはこの定量は意味があ ると考える。もちろん、より詳しい検査として 大型弱視鏡にて回旋偏位を測定するのは大切で ある。

\section{Bielsowsky 頭部傾斜試験の用い方 検查距離

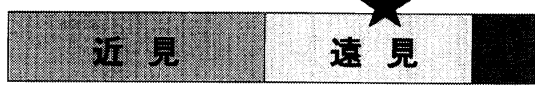

\section{定性·定量のどちらを通常行っているか？}

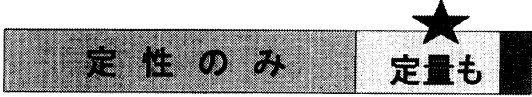

図 8.アンケート結果 $(3)$

高齢化社会を迎えつつある昨今、Skew deviationの様な症状の高齢者をよく経験する。 眼球運動自体には特に制限はないが、眼位はわ ずかに上下偏位が確認でき、本人は上下の複視 に悩まされている。MRIなどを施行してもはっ きりした原因は認められない場合が多い。この 場合は 5 方向カバーテストが非常に有用で、そ の結果でほぼ診断が可能な場合もある。上下の 偏位角はわずかで、各むき眼位での変動も少な いので、そのデー夕をもとにプリズム眼鏡を合 わせるとほとんど複視が消失し効果的である。 この疾患は最も 5 方向カバーテストが有用な疾 患ではないかと考える。

3 方向や 5 方向カバーテストの手技は、遠見
視標を用いて普通に第一眼位をプリズムにて定 量したあと、垂直 3 方向の場合は顎を挙げた状 態で視線だけ第一眼位を測った時と同じ視標を 見てもらい、下方視時の偏位角を測定し、次に 顎を下げてもらい、視線ははじめと同じ遠見視 標を注視させ、上方視時の偏位角をプリズムで 定量する。

水平 3 方向の測定の要領も同様で、顔を右へ まわし視線は正面の遠見視標を注視させ、左方 視時の偏位角を測定し、次は逆に顔を左にまわ し、右方視時の偏位角を定量する。

\section{IX．カバーテストが不向きな症例}

臨床的には、眼位異常を訴える中にもカバー テストが不向きな難しい疾患もあり、その見極 めも必要となる。動眼神経麻瘏の場合、外転以 外のすべての動きが制限されているので、カ バーテストで整復運動などをチェックしても二 次偏位が大きく関与し、自然な眼位を計測する ことは難しく、Hirschberg法や Krimsky法が検 查の中心となり、写真による記録などが有用と なる。っこのような場合に無理にカバーテスト で定量を試みることは逆効果と考える。

進行性外眼筋麻瘏では、上眼瞼挙筋も障害さ れてかなりの下垂を呈し、正確な眼位が測定し にくい。その上、眼球運動も不規則に制限され ており変動が激しく、むき眼位での定量は難し い。重症筋無力症やフィッシャー症候群なども 同様である。このような場合は第一眼位のみ素 早く定量する。

デュアン症候群では、異常神経支配のために 眼球運動が制限されており、多くは目立たない 程度に頭位異常をとっている場合が多い。例え ば I 型で外転不能のタイプで、患側方向を向い た時に内斜視に見えるが、これは本来は斜視で はないことを説明して、もちろん治療はせず経 過観察をする。しかし、実際には斜視が合併し ていることもあり、第一眼位が本当に正位か斜 視かを見分けるのは意外に難しい。もし正面の 位置の設定をルーズに取り扱っているとカバー テストをした時に内斜視に見えることは多く、 低年齢であるほど信頼性がそしくなる。当院で 
も急いで手術を行い、かえって外斜視を作って しまった経験もある。やはり斜視の有無を確認 する上で慎重さの必要な疾患である。

\section{X。まとめ}

遮閉試験は、日常臨床において誰もが行って いる基本的な検査法である。しかし、その用い 方や具体的な内容は今回アンケートなどの結果 からも明らかにされたように意外に違いがみら れ、今後検討の必要性がある課題も残された。 本報であげた筆者自身の遮閉試験のポイントを 整理して示すと：(1)調節視標の意義と遮閉具の 使い分け (2)間歇性外斜視の潜伏された偏位を 引き出す方法 (3)遠見でのBielschowsky頭部傾 斜試験 (4)むき眼位の臨床的有用性となる。

稿を終えるにあたり、ご指導、ご校閲いただき ました当教室池田恒彦教授ならびに内海 隆非 常勤講師に深謝いたします。

\section{文献}

1) 丸尾敏夫、粟屋 忍: 視能矯正学. 221-224、 金原出版、東京，1994
2 ）白井千恵：眼位の検査.植村恭夫（編）：視能 矯正マニュアル、211-213、メディカル葵出 版、東京, 1998

3 ）渡辺好政：眼位・眼球運動検査.丸尾敏夫 (編)：眼科検查ハンドブック、78-82、医学 書院、東京, 1999

4 ) 山本裕子：斜視・弱視の診断検查法、医学書 院、東京, 1982

5 ) 中川 喬 : cover testの使いわけ.小暮文雄 （編）：眼科検査・診断のコツと落とし穴、84、 中山書店、東京， 1996

6 ）田中靖彦：乳幼児の眼位眼球運動検査.小暮文 雄（編）：眼科検査・診断のコッと落とし穴、 89、中山書店、東京, 1996

7 ）金谷まり子：間歇性外斜視視の視能矯正的検 査法.視能訓練士協会誌 $28 ： 21-28,2000$

8 ）矢ケ崎悌司：プリズムバーの正しい持ち方. 小暮文雄（編）：眼科検査・診断のコツと落 とし穴、86-87、中山書店、東京, 1996

9 ）清水みはる、菅澤 淳、他：間歇性外斜視の 遮閉試験による術前眼位変化の検討. 眼臨 93：902-905, 1999

10）清水みはる、菅澤 淳、他：間歇性外斜視の プリズム装用における眼位変化の検討（遮閉 法と比較して)．眼臨94：760-762，2000 